\title{
MEMÓRIA E COMEMORAÇÃO
}

Maria Isabel João*

\section{Resumo}

Este texto explora as articulações entre a memória coletiva das nações portuguesa e brasileira e as comemorações do descobrimento ou achamento do Brasil, desde o século XIX até 2000. Analisa, ao longo do tempo, as diferentes imagens construídas das relaçōes Brasil/Portugal, como por exemplo, de pai para filho e entre irmãos (comunidade lusófona imaginada).

Palavras-chave: Memória coletiva, descobrimentos, comemoração.

A recordação - através de práticas ritualizadas - de acontecimentos que interessam a uma comunidade tem uma origem remota e uma larga tradição. Para não irmos mais longe, basta recordar que uma parte importante dos dispositivos modernos das comemorações remontam à civilização greco-romana e ao período clássico. Discursos, récitas, lápides, arcos triunfais e monumentos já então serviam para celebrar as grandes vitórias nas batalhas e os homens que as tinham liderado. Essa evocação não se pode dissociar de uma dupla necessidade que é comum a todas as sociedades: a legitimação do poder instituído, que procura na apropriação presente desses acontecimentos e figuras uma forma de marcar a continuidade com um passado glorioso, e a afirmação da identidade colectiva, que se estriba na memória de um percurso histórico

* Professora Doutora da Universidade Aberta de Lisboa. 
inventado e reinventado pelos grupos humanos ao sabor dos seus interesses, emoções, sentimentos e valores.

A própria História nasce da necessidade de conservar a memória, como escreveu Heródoto (1990, p. 7-9) no início da sua narrativa das guerras médicas. As fronteiras entre ambas têm sido ténues e muito difíceis de estabelecer na prática. A memória é o oceano donde emerge a História e no qual essa história volta a mergulhar na medida em que as sociedades se apropriam de suas narrativas. A História implica um esforço de pesquisa, de recolha de diversos testemunhos, de apuramento dos factos e de avaliação desses factos de forma serena e reflectida, o que acaba por distingui-la da memória, mais dada ao sentimento do que à razão. A História empenha-se em conhecer e compreender o passado. Não tem de julgar nem de condenar. Também não tem de glorificar, enaltecer ou celebrar, porque dessa forma cairia no mito ou, eventualmente, na mistificação. O historiador precisa, isso sim, de utilizar os instrumentos metodológicos e conceptuais da sua disciplina para apreender as realidades do passado de uma forma tão precisa e completa quanto for possível. A História não é definitiva e está sujeita à dúvida, à crítica e à reformulação. As suas verdades não são únicas e muito menos simples, o que geralmente não agrada a quem procura uma visão em preto e branco de bons e de maus, de heróis e de vilões. O historiador tem de estar consciente da distância que o separa do passado. Como referiu-se L. P. Hartley, "the past is a foreign country: they do things differently there" (RowLAND, 1987, p. 7). Tal como o antropólogo tem de exercer uma permanente vigilância crítica para não analisar as outras culturas e sociedades pelo prisma da sua, também o historiador não pode cair no erro de transpor o presente para o passado.

Nos últimos decénios, a História tem alargado o seu objecto de estudo e resgatado do esquecimento muitos aspectos da vida das sociedades e dos povos que antes não despertavam o interesse dos historiadores. Vários grupos humanos antes ignorados ou menosprezados pelas mais diversas razões entraram no domínio da historiografia, que deixou de se referir somente aos grandes e poderosos. A História tornase, deste modo, mais inclusiva. Ao mesmo tempo, através da História da História, os historiadores vão tendo uma consciência mais aguda dos limites da produção do conhecimento histórico. Ver a historiografia em perspectiva histórica, sujeita às contingências humanas, sociais e políticas 
e à transformação no tempo é a melhor maneira de perceber o carácter frágil, relativo e mutável do conjunto de saberes que constituem esta disciplina, como qualquer outra disciplina científica. Por isso, mais do que nunca a História questiona-se, torna-se problemática, complexa e distancia-se das verdades simplistas em que assentam o senso comum e as convicções ideológicas. Assim sendo, os seus discursos tornam-se mais difíceis de reduzir a slogans ou a chavões que condensem uma imagem, ou seja, uma ideia assumida como emblema de um dado grupo social ou de uma comunidade.

A História não passa certidões de nascimento aos países, às sociedades ou às culturas. Quando muito pode contribuir para elucidar os complexos factores e processos através dos quais uma nação se foi constituindo como tal ao longo do tempo. Sabemos nós, desde a célebre conferência de Renan na Sorbonne, em 1882, que uma nação resulta de um esforço colectivo, de uma vontade de ser uma comunidade e, nesse sentido, está sujeita a um plebiscito quotidiano. Assim sendo, o lema oficialmente adoptado para as comemorações do descobrimento do Brasil pelos portugueses em 1500, "Brasil 500 anos" - um lema que até deu origem à rábula dos relógios que iam apresentando a contagem decrescente do tempo para o nascimento do país - é um slogan eficaz em termos de um certo tipo de memória colectiva que se pretende construir, mas não faz justiça à história da nação brasileira. Primeiro, o descobrimento, por uma armada portuguesa, de um território antes desconhecido, ou do qual se suspeitava a existência e se tinham vagas referências, não foi sequer o primeiro passo para a colonização da Terra de Santa Cruz. A Coroa portuguesa achou-se com direito a tomar posse da terra descoberta, mas só mais tarde tomou as providências necessárias para ocupar, povoar e administrar o novo território. Segundo, o longo processo de colonização do território, em que os elementos indígenas, africanos e europeus se entrecruzam de uma forma que seria estultícia querer destrinçar, é que foi a base da construção da nação brasileira. Só no século XIX a nação, lentamente construída, se constituiu como Estado independente e começou a reunir as condições para uma afirmação mais completa, no contexto do desenvolvimento das concepções românticas e da expansão do movimento das nacionalidades, que também na Europa levou diversos povos a lutar pela sua emancipação política. A partir desse momento, a nação inventa-se e reinventa-se através do 
discurso das suas elites, que procuram na história os elementos susceptíveis de servir de âncora à construção da memória colectiva e da identidade nacional.

É evidente que essas elites são brancas ou mestiças, formadas segundo os valores dominantes nos séculos XIX e XX. Por isso, a ideia de um nascimento do Brasil com a chegada dos europeus ao Novo Mundo, fazendo uma espécie de tábua rasa dos povos e das culturas autóctones e do contributo dos escravos africanos para a construção do Brasil, marcou os discursos e os imaginários. Os brasileiros eram os "nativos", isto é, os nascidos na colónia, que se opunham aos que vinham do Reino e com eles rivalizavam na economia e na administração. Mas, desse grupo "nativo" que disputava o poder económico e político aos rẹinóis, estava naturalmente excluída a maioria dos índios e dos negros. Assim, a invenção de uma identidade nacional brasileira fez-se "branqueando" a história do Brasil e afirmando como cultura dominante os elementos colhidos da matriz europeia, ao mesmo tempo que, de um ponto de vista político, o Brasil se separava da Metrópole e se constituía como Estado independente. Houve, assim, um duplo movimento de assimilação e de rejeição: de assimilação da cultura portuguesa e de rejeição do seu domínio político e económico.

Não é só o processo da transição para a independência, relativamente pacífico e indolor, que pode explicar o sucesso e a longevidade desta ideia de um nascimento do Brasil em 1500, a qual subestima os índios e distorce os factos históricos. É a identificação do Brasil com uma origem europeia que domina a imagem que as elites nacionais têm de si e, por extensão, do conjunto do país, apesar dos manifestos antropofágicos e de um multiculturalismo superficial, importado dos Estados Unidos, muito mais recente. Essa imagem corresponde à realidade? Eis a questão óbvia que temos de colocar. No plano da cultura dominante, aquela que, afinal, constitui a base da identidade do Estadonação e da sua unidade política, e que se tem conservado apesar da tensão entre centralismo e federalismo, não há dúvida quanto à importância decisiva dos elementos culturais herdados do país colonizador. A língua única e comum a todo o país é a expressão mais forte dessa herança. Mas se pensarmos na realidade sociocultural mais profunda do Brasil, nas populações indígenas e negras marginalizadas, na diversidade resultante do facto de ser este um país de imigrantes, 
constituído por múltiplas comunidades com características próprias e por regiões que foram desenvolvendo idiossincrasias e particularidades, então a ideia da nação torna-se muito mais rica e complexa, e os elementos da matriz cultural portuguesa estão imbricados com outros, por vezes diluídos, num puzzle complexo e em contínua transformação.

"Brasil 500 anos" é, deste modo, uma fórmula que traduz bem um certo imaginário - por isso foi bem sucedida e teve eco nas populações - e resume a ideia de que a chegada de Pedro Álvares Cabral e a carta de Pêro Vaz de Caminha são o momento fundador do Brasil. Normalmente, as nações e os regimes políticos precisam definir a sua data de nascimento e fazem-no buscando o acontecimento que pode ser tomado como mais emblemático. Os portugueses continuam até hoje a pensar que o D. Afonso Henriques, herdeiro de um nobre da Borgonha e de uma leonesa que foram senhores do Condado Portucalense, fundou a nacionalidade no século XII. Imputam-lhe um objectivo que não teve nem poderia ter tido: o homem só queria ser rei e cortar os laços de vassalagem com o primo. Mas a ideia de um momento fundador, uma vez instalada na memória colectiva, estabelece a origem e a antiguidade da nação.

Ora, o Brasil costumava inclinar-se para o 7 de Setembro, que tem sido a data comemorada como símbolo da independência e, logo, como momento da fundação do país. Os românticos e, sobretudo, os positivistas e republicanos criaram os grandes mitos de identificação nacional em torno da figura do Tiradentes, curiosamente assimilado a Cristo na iconografia, e desse grito pela independência soltado pelo príncipe D. Pedro, nas margens do rio Ipiranga. Em relação a esta data, a do descobrimento tem, entretanto, a vantagem de recuar no tempo a origem, de dar mais força à ideia da antiguidade do país, do peso da história e da continuidade, nesta época rápida de globalização e de comunicações instantâneas em que as comunidades se aferram às tradições e às identidades como a uma bóia de salvação no meio da borrasca. Revela também a maturidade do Brasil como nação que já não desdenha a herança colonial, antes a incorpora na sua retórica das origens e identitária, marcando a diferença em relação aos países vizinhos e fazendo a ponte com o outro lado do Atlântico. Líder num espaço económico regional alargado e desejoso de se afirmar como porta-bandeira dos países do Sul e do Terceiro Mundo, o Brasil procura nas relações 
com a Europa o contrapeso à presença dominante dos Estados Unidos no continente americano, e Portugal, país da União Européia, pode ser uma boa porta de entrada. Quanto mais não fosse, só por isso o governo brasileiro estaria interessado em participar nas comemorações dos 500 anos e em tornar a data em algo mais do que a obscura chegada de uma armada que até ia em demanda da Índia, a terras de uma gente de "cor baça e cabelo corredio" de que ninguém recorda o verdadeiro nome.

Ao instituir uma data como momento fundador, já estamos a sair do campo da História para o da memória, do campo dos factos para o dos mitos. Retroprojecta-se no passado o conhecimento do que ocorreu depois e isola-se um acontecimento, às vezes um mero episódio mal contado - como no caso da célebre cena do Ipiranga - que é transformado num marco emblemático de uma comunidade. E a data torna-se objecto de rituais de celebração colectiva, de comemoração. Pode ser vista pelo prisma eufórico, de uma marcha de sentido positivo, quiçá gloriosa e heróica, em direcção ao porvir, ou pelo lado disfórico, do sacrifício, sofrimento e tragédia. Essas duas posições estiveram em evidência, em 1992, nas comemorações da viagem de Cristóvão Colombo. No Brasil, o contraponto às comemorações oficiais foram os " 500 anos de luta e luto" das organizações indígenas contra a conquista, a opressão e o genocídio. Não deixa também de ser uma comemoração - que significa recordar em conjunto - e uma forma de mitificação da história, porque a reduz a um único vector destinado a afirmar a condição de vítimas de uma parte da população e a sustentar reivindicações sociais. Em qualquer dos casos, o processo histórico é visto de forma unilateral e apropriado como elemento de uma memória colectiva que funciona como factor de identificação e de reconhecimento de diversos grupos sociais e comunidades.

Muito se tem discutido o uso do termo "descobrimento", e alguns defendem mesmo que se devia bani-lo do vocabulário, porque comportaria um olhar de superioridade dos europeus, os descobridores, sobre os povos descobertos. Mas não é na palavra que está a origem do mal, nem ela significa o que lhe quiseram atribuir. Como exaustivamente mostrou Vitorino Magalhães Godinho (1994), "descobrir", "achar" são termos que se encontram nas fontes portuguesas dos séculos XV e XVI, que traduzem a ideia da revelação das partes encobertas, desconhecidas do mundo. Garcia de Resende, citado por Godinho (1994, p. 7), resumiu 
bem a admiração dos homens da sua época perante a novidade: "Outro mundo encoberto / Vimos então descobrir / que se tinha por incerto"; ou noutros versos igualmente sugestivos: "Outro mundo novo vimos, / pela nossa gente achar, / e o nosso navegar / tão grande, que descobrimos / cinco mil léguas pelo mar" (GodinHo, 1994, p. 26). Para se descobrir realmente uma terra nova era preciso ir em sua busca, tendo uma ideia do que se procurava, mesmo que fosse vaga ou errónea, e conseguir voltar ao reino com a novidade. O regresso era fundamental e determinava se uma terra tinha sido, ou não, descoberta. Assim, os portugueses descobriram os rios da Guiné porque conseguiram traçar uma rota para o regresso em arco de círculo, aproximando-se dos Açores e contornando os alíseos e a corrente de nordeste por navegação distante da costa. Além disso, graças à invenção da caravela (cerca de 1.440 ) podiam avançar com vento pela proa. "Descobrimento", "achamento", que foram os termos usados por Caminha na carta ao rei D. Manuel, são termos que não têm em si mesmos um significado que não seja o de encontrar, achar pela primeira vez, pôr à vista, dar com o que estava oculto e conseguir conhecer o que era ignorado ou que estava encoberto.

Porém, a busca sistemática de novas terras tem aqui vários outros objectivos: tomar posse, conquistar, fazer o comércio, evangelizar, acrescentar o poder e a riqueza da Coroa e dos vários grupos sociais envolvidos na empresa dos descobrimentos. O acto de "descobrir" tem, inegavelmente, um lado positivo que se prende com conhecer o mundo e colocar em contacto regiões antes isoladas e povos que se desconheciam. Mas acarreta consigo, além disso, a expansão territorial dos reinos europeus e a formação de grandes impérios ultramarinos. É uma história com vencedores e com vencidos, naturalmente. E é uma história que pode ser contada, e tem-no sido, de várias perspectivas. As fontes escritas europeias, árabes e asiáticas da época e a tradição oral de povos como os índios do Peru, estudada por Nathan Wachtel (1971), são disso a prova. Mesmo as fontes portuguesas não apresentam todas uma visão idêntica dos factos, e os relatos crus dos actos de pirataria, das guerras e dos morticínios são bastante freqüentes. Só mais tarde houve a preocupação de escamotear esse lado da história, sobretudo nos relatos de divulgação para o grande público e no sistema de ensino. A evolução das mentalidades, decorrente da penetração das ideias humanistas e dos movimentos abolicionistas, que se desenvolveram na Europa no século 
XVIII, tornou reprováveis esse tipo de actos que manchavam os feitos dos antepassados. A tendência para esquecer o lado tenebroso da história é o resultado de se entender que esta deveria servir de proveito e exemplo para o povo e as novas gerações, além de ser uma consequiência da necessidade de identificação com os antecessores e com o passado comum. Ora, no quadro da transformação dos valores partilhados pelas sociedades contemporâneas, muitas acções passaram a ser reprovadas e censuradas, entrando para o limbo do esquecimento. Mas basta ler as fontes da época para se recuperar a lembrança, o que é uma tarefa do historiador e de uma memória histórica informada, correcta e plural.

O etnocentrismo não é exclusivo das crónicas e da história contada pelos europeus. Partir de "nós", vendo-nos como o centro do mundo e como portadores de virtudes e valores superiores, é uma atitude muito generalizada que faz parte da forma como as sociedades humanas percepcionam a realidade, como mostrou o antropólogo Claude LéviStrauss (1980, p. 21). ${ }^{1}$ Quando os homens da armada de Cabral desembarcaram na Terra de Santa Cruz, os tupis-guaranis - mais bem organizados, mais bem armados, dispondo das técnicas de agricultura de coivara e da cerâmica, bem como da construção de habitações, estruturas defensivas e canoas - efectuavam grandes esforços para completar a conquista da faixa litoral e desalojar as populações que aí viviam. Estas foram apodadas de "tapuias", vocábulo tupi que significa "selvagens" e que era utilizado depreciativamente para se referir aos inimigos que não tinham atingido o nível técnico e de organização social dos conquistadores (Couto, 1995, p. 60). Quando entraram em contacto com os tupis, os portugueses, transmitiram-lhes o seu menosprezo por esses povos, que um missionário jesuíta descreveu, em 1555 , do seguinte modo:

geração de índios bestial e feroz; porque andam pelos bosques como manadas de veados, nus, com cabelos compridos como mulheres; a sua fala... mui bárbara e eles mui carniceiros e trazem flechas ervadas e dão cabo de um homem num momento. (Couto, 1995, p. 60)

A visão negativa deste grupo de índios, considerados inferiores, tornou-se comum aos povos tupis e aos portugueses. 
O historiador não pode contar a história na perspectiva de um dos contendores. Tem de se distanciar, expor e analisar os vários lados da questão, compreender os interesses que estavam em jogo, as mentalidades próprias de cada época e ver os comportamentos humanos inseridos nos respectivos contextos. De facto, em 1500 uma armada comandada por Pedro Álvares Cabral achou, descobriu uma região a que foi dado o nome de Terra de Santa Cruz e, mais tarde, de Brasil. Mas o Brasil como Estado e como nação ainda não existia e demorou vários séculos a ser edificado. O território teve de ser desbravado, com a ajuda imprescindível dos conhecimentos dos índios e das suas técnicas de sobrevivência nas matas tropicais. As fronteiras tiveram de ser conquistadas e negociadas pela diplomacia, embora as negociações não tenham sido definitivas. Como todos os grandes países do Novo Mundo, o Brasil é um país com fronteiras em permanente mobilidade interna, porque vastas regiões só lentamente foram sendo ocupadas e trabalhadas pelo homem - sua última fronteira é a Amazónia, que tem vindo a ser desbravada, e destruída, à grande velocidade nas últimas décadas. Para produzir a riqueza da colónia e, depois, do país independente foram necessários senhores e escravos, o que deixou uma marca pesada nas estruturas sociais e nas mentalidades. Foi também necessário o contributo de muitos povos imigrantes e até dos portugueses que, no século XIX e $\mathrm{XX}$, afluíram em grande quantidade em busca das condições para sobreviver e da riqueza que escasseava - além de estar mal distribuída - no seu país. A colonização portuguesa moldou o país e, posteriormente, os imigrantes continuaram a dar o seu contributo para criar a riqueza $e$ a cultura do Brasil. Assim sendo, os laços históricos são, efectivamente, muito fortes.

Por isso, em quadros políticos muito diferentes e por razões que têm de ser analisadas para cada conjuntura, os governos portugueses promoveram a comemoração de centenários relacionados com o Brasil. A primeira comemoração foi em 1900 , para recordar o quarto centenário da descoberta; a segunda foi em 1922, quando os republicanos portugueses se associaram ao centenário da independência do Brasil; a terceira, que vamos referir no nosso artigo, foi o quinto centenário do achamento, em 2000. Três regimes políticos muito distintos - a Monarquia Constitucional, a Primeira República e a Terceira, saída de um golpe de Estado e de um processo revolucionário que derrubou uma longa ditadura 
de quase meio século - sentiram a necessidade de recordar e celebrar o Brasil. Afinal, é isso que tem estado em foco nos centenários, porque o que interessa comemorar é o presente e não o passado. A memória colectiva só se detém naquilo que lhe diz alguma coisa hoje. Se os portugueses não tivessem colonizado o Brasil, entusiasmados como andavam naquela época com as especiarias do Oriente, e se o Brasil não existisse como nação com as características que fazem dele o maior país de língua portuguesa, não haveria motivo para comemoração. Ninguém se lembraria da viagem da armada de Cabral, como já não são recordadas muitas das descobertas e odisséias que permitiram dar a conhecer o mundo.

Não tenhamos dúvidas de que é o presente que determina o interesse colectivo pelo passado ou, melhor dizendo, por parte dele. Aquela parte do passado que serve para sustentar afirmações de identidade, definir origens, enaltecer feitos e contribuições para o percurso da humanidade, justificar causas e reivindicações, como as indemnizações pela escravatura, propostas por certos grupos de activistas afro-americanos, ou, o seu antecedente, a criação de um Estado judaico na Palestina, justificado pelo holocausto dos judeus. O passado como um todo é o objecto de estudo dos historiadores, mas uma grande parte do que desenterram da poeira dos arquivos e dos sítios arqueológicos permanece no domínio de uma minoria de especialistas. A história viva, aquela da qual se apropria a memória colectiva e que dá o mote para celebrações públicas, é muito selectiva e feita mais de esquecimento do que de lembrança. Já Renan tinha afirmado, na conferência em que respondia à pergunta "Qu'est-ce qu'une nation?", que "a essência de uma nação é que todos os indivíduos tenham muitas coisas em comum, e também que todos tenham esquecido muitas coisas". Só a recordação selectiva e o esquecimento podem manter viva a "comunidade imaginada" que é a nação (ANDERSON, 1991), fruto de muitas vicissitudes e de muitos confrontos.

Além de tornarem presente o passado, de o "presentificarem", se quisermos criar um termo novo, as comemorações procuram servir para unir os cidadãos em torno de imagens, símbolos, referências e valores susceptíveis de dar força e coesão ao corpo da nação. De um ponto de vista externo, visam projectar imagens que contribuam para singularizar e identificar o país, para lhe dar visibilidade e um estatuto de 
prestígio. Assim, a imagem actual da França é indissociável da Revolução Francesa, e a comemoração dos seus centenários teve assinalável repercussão internacional. A imagem da Itália está muito ligada à cultura e, sobretudo, às grandes figuras do Renascimento, que têm dado origem a celebrações em todo o mundo culto ocidental. A Alemanha tem procurado celebrar o "génio" alemão como factor de identificação de todos os seus cidadãos e de afirmação de uma imagem positiva de grande nação de cultura, contraposta à visão prussiana e militarista do seu passado. A Grã-Bretanha tem investido especialmente em reinventar a tradição de uma monarquia que funciona como factor de unidade de um vasto complexo de povos e nações. A Espanha, país composto por várias nacionalidades, tem buscado na celebração da "hispanidade" e da descoberta da América por Cristóvão Colombo, comemorada a 12 de outubro, uma forma de afirmar uma identidade transnacional e um amplo espaço de intercâmbio económico, político e cultural. Os Estados Unidos têm alimentado o culto dos Pais Fundadores da nação, a evocação dos primitivos colonos e dos pioneiros do Oeste americano como uma forma de cimentar a unidade nacional e de associá-la à ideia do sacrifício e do heroísmo que foi necessário para construir o país. Portugal, por sua vez, desde pelo menos os grandes centenários do final do século XIX, tem procurado afirmar uma imagem de país de navegadores, de descobridores, de um povo que abriu "novos mundos ao mundo".

Qualquer destas imagens tem um fundo de verdade, mas constitui somente uma parte dela. Aquela que melhor propicia uma auto-imagem colectiva favorável e ajustada à necessidade de uma projecção externa positiva dos países. Cada época e regime político promove as suas próprias comemorações, mas algumas apresentam um carácter transversal e são recorrentes porque se prendem com os grandes mitos em que se tem sustentado a identidade nacional. É o caso das comemorações dos descobrimentos e do grande poeta da nação, Luís de Camões, celebrado no dia 10 de Junho, em Portugal, ou do Dia da Independência, no Brasil. Nenhum governo brasileiro quer deixar passar a data de 7 de Setembro sem celebração, e é nos momentos de crise que a necessidade de afirmar o patriotismo se faz mais acentuada e as comemorações ganham um cunho político mais forte de apelo à unidade e mobilização nacional. ${ }^{2}$ Os contextos políticos, os tipos de iniciativas, a tónica dos discursos são fundamentais para se fazer a história das comemorações. 
É o que demonstraremos em relação à celebração dos três centenários já referidos, os de 1900, 1922 e 2000. Pretendemos mostrar, em seguida, a forma como essas datas foram comemoradas em Portugal.

\section{O quarto centenário da descoberta do Brasil}

Em Portugal, a proposta para se celebrar o quarto centenário do descobrimento oficial do Brasil partiu da Sociedade de Geografia de Lisboa, que não queria deixar passar a data sem recordar o feito da armada comandada por Pedro Álvares Cabral. O assunto foi debatido na sessão de 12 de Fevereiro de 1900, mediante o parecer apresentado pela Comissão Americana. Mas a difícil conjuntura nacional reduziu, logo de início, o âmbito das propostas para o centenário. Na introdução ao seu parecer, a Comissão recordava as dificuldades económicas do país e defendia que a "importância das homenagens não está no seu valor intrínseco mas na maneira sincera como são prestadas" (Boletim da Sociedade de Geographia de Lisboa, 1901).

$\mathrm{Na}$ Sociedade de Geografia estavam os principais responsáveis pela organização de várias celebrações nacionais e, em especial, pela importante comemoração do descobrimento do caminho marítimo para a Índia que decorreu em 1897-1898. As dificuldades financeiras e logísticas, a par do desinteresse dos governos e dos poderes instituídos, demasiado absorvidos com os gravíssimos problemas económicos e políticos do país, semearam de escolhos a tarefa dos organizadores do chamado "Centenário da Índia" e tornaram menos apetecível a repetição de iniciativas congéneres. Além disso, tinha sido implantada a República no Brasil, e as relações políticas entre os dois países atravessavam um momento de tensão e dificuldades, agravadas pela perseguição à comunidade portuguesa, movida pelos republicanos mais radicais, em particular no Rio de Janeiro (RIBEIRo, 2000, p. 69-84). Muitos portugueses eram pequenos ou médios comerciantes $\mathrm{e}$, por isso, um alvo fácil do descontentamento popular. Por tudo isto, o centenário passou quase despercebido.

Apesar de modesto, o projecto da Comissão Americana não chegou a ser concretizado. Em Lisboa, numa sessão solene na Sociedade de Geografia, a 5 de maio de 1900 (Boletim da Sociedade de Geographia de Lisboa, 1901), a celebração oficial, sob a presidência do rei D. Carlos, 
ficou circunscrita à evocação de Pedro Álvares Cabral e do seu feito. O governo decretou "dia de gala" naquela data, e em várias cidades do país foram promovidas conferências e sessões públicas para recordar a efeméride. ${ }^{3}$ Também no Brasil, a data foi assinalada com algumas celebrações públicas que tiveram um eco bastante limitado. O Estado português enviou como seu representante às comemorações brasileiras o general e conselheiro Francisco Maria da Cunha, uma figura do regime monárquico e constitucional, que foi acompanhado por uma comitiva oficial. As relações com a jovem República do Brasil eram muito importantes para os governos portugueses por várias razões, entre as quais avultavam as transferências das receitas dos emigrantes, que contribuíam para equilibrar a sempre periclitante balança de pagamentos do país.

A delegação deslocou-se num navio de guerra e chegou com alguns dias de atraso, mas ainda pôde participar nas principais cerimónias do programa oficial das comemorações. Em particular, merece destaque o facto de o descerramento do monumento dedicado a Pedro Álvares Cabral, do escultor Rodolfo Bernadelli, ter sido inaugurado em conjunto pelo representante de Portugal e pelo presidente da República do Brasil na cidade do Rio de Janeiro. Além de Cabral, o monumento homenageia também o escrivão da armada, Pêro Vaz de Caminha, e frei Henrique de Coimbra, que rezou a primeira missa no Brasil. ${ }^{4} \mathrm{Em} 1940$, o governo brasileiro ofereceu a Portugal uma réplica do monumento, que foi descerrada, em Lisboa, no âmbito das comemorações do Duplo Centenário da Independência e da Restauração de Portugal.

A imprensa portuguesa referiu-se ao quarto centenário do descobrimento e noticiou os festejos realizados no Brasil. Em especial, a revista Brasil-Portugal, editada em Lisboa, fez uma larga cobertura dos acontecimentos e publicou um número especial dedicado ao centenário, que reuniu uma importante colaboração de autores nacionais. ${ }^{5} \mathrm{O}$ centenário teve, por conseguinte, alguma expressão em ambos os lados do Atlântico. De um ponto de vista geral, as posições ideológicas e a visão da história subjacentes às comemorações não eram muito diferentes nos discursos oficiais. As navegações europeias e, em particular, os descobrimentos portugueses eram vistos como uma grande gesta colectiva que tinha permitido aproximar os continentes e desbravar regiões até então desconhecidas. Mas mais importante do que isso era o facto 
de esses descobrimentos terem permitido estabelecer o domínio da Europa sobre o mundo e contribuído para trazer ao grêmio da Civilização, como então se dizia, vastas áreas e povos do globo.

Entendia-se que a colonização europeia era uma prática civilizadora e que a humanidade caminhava num sentido de evolução e progresso que conduziria, inevitavelmente, os povos colonizados a aproximaremse dos padrões culturais e de desenvolvimento dos colonizadores. Os países do Novo Mundo - e, neste caso, o Brasil - eram considerados um bom exemplo desse processo económico, político e cultural que tinha permitido criar sociedades à imagem e semelhança das europeias. As elites portuguesas orgulhavam-se do grande esforço feito pelos seus antepassados e dos resultados que tinham sido alcançados naquela região da América Latina. Pelo menos os sectores mais cultos e informados do ponto de vista histórico não esqueciam que a grande nação latinoamericana, com o seu vasto território e uma língua comum, tinha sido fruto da colonização portuguesa.

Neste sentido, o descobrimento do Brasil foi comemorado, em 1900 , como o início da sua história. Por um lado, considerava-se que os primitivos habitantes do Brasil, pelo facto de serem povos sem escrita, estavam na Pré-História e, por isso, a chegada dos europeus é que tornara possível o ingresso daquela região do mundo na História. E, por outro lado, entendia-se que o Brasil era uma criação de Portugal e dos portugueses. Um jornalista escrevia nesta ordem de ideias:

O Brazil não existia antes do descobrimento, nem ficou existindo pela realização d'este. O Brazil, imediatamente à empreza de Álvares Cabral, ficou sendo apenas uma designação, um nome, de uma paragem transoceanica, d'ahi em diante marcada nas cartas. [...] O Brazil que descobrimos nãoé, pois, na realidade das cousas, o Brazil pelo qual nos glorificamos. Este é outro Brazil, muito diverso: é o Brazil que nós creamos, que nós fizemos. (Commercio do Porto, 8/5/1900)

O autor deste artigo concluía que Portugal já não poderia morrer como Nação, pois iria sobreviver no Brasil: "n'elle estamos continuados e renovados; n'elle somos reconhecidos pelos povos que nos rodeiam; n'elle, finalmente, continuamos, pela perpetuidade dos tempos, a sermos nós". 
A ideia do Brasil como uma continuação de Portugal na América foi um dos tópicos mais significativos dos discursos comemorativos. $\mathrm{O}$ Brasil e os brasileiros não eram vistos numa óptica de alteridade, mas como uma parte de nós. Eram também considerados o exemplo máximo da capacidade de Portugal como país colonizador, de tal modo que o grande objectivo do colonialismo português, no século XIX e mesmo mais tarde, consistia em criar "novos Brasis" em África.

O feito de Pedro Álvares Cabral assumia, deste modo, o valor de um acontecimento fundador da história e da nação brasileira. Nisto residia a sua importância para a memória que as elites dirigentes portuguesas e as brasileiras pretendiam construir como elemento de identificação nacional. A polémica historiográfica bastante viva sobre as circunstâncias que rodearam o achamento do Brasil era, naturalmente, um problema que interessava a um universo restrito de cidadãos. A própria data da comemoração em Portugal, oficialmente fixada em 5 de Maio, não respeitou o que já se sabia sobre o dia da chegada da armada à região de Porto Seguro, que ocorrera a 22 de Abril.

O quarto centenário do descobrimento do Brasil foi o pretexto para a publicação de vários romances históricos, um gênero bastante popular na época, além de relatos que tomavam por base a famosa carta do escrivão Pêro Vaz de Caminha para o rei D. Manuel a dar conta da descoberta (Pimentel, 1900; MendonçA, 1899; FonseCA, 1900). A visão dominante neles em relação aos índios era de povos que viviam num estado natural ou selvagem, mais próximo da condição animal ou da infantilidade. Mas o olhar simpático de Caminha não deixou de influenciar as narrativas do século XIX. Por um lado, continuava presente a ideia da inocência dos índios, bem demonstrada pela forma como exibiam os seus corpos nus sem qualquer pudor. Pêro Vaz de Caminha chegou mesmo a estabelecer comparação da inocência deles com a de Adão no Paraíso. Por outro lado, não era ignorada a beleza física dos homens e das mulheres, o carácter bom e a simplicidade dos seus costumes, a amabilidade que demonstraram em relação aos portugueses, ultrapassadas as primeiras reacções esquivas e de natural desconfiança.

Num dos romances, o autor concedeu mesmo ao personagem que simboliza o índio uma certa superioridade moral em relação ao português que com ele rivaliza no amor, porque, como afirma no prólogo, "a civilização tem sido muitas vezes mais bárbara do que a barbárie" 
(Pimentel, 1900). Ecoa neste texto a ideia romântica do "bom selvagem", o que não se verifica noutros relatos que foram vulgares naquela época. Os autores do século XIX não ignoravam as descrições das práticas de canibalismo, que tinham chocado os europeus quando se inteiraram melhor dos costumes indígenas. A antropofagia era, por conseguinte, um dos elementos mais importantes de uma visão bastante generalizada sobre os índios, que ressaltava a imagem da selvajaria e da ferocidade. Fora destas generalidades, havia um grande desconhecimento sobre a história e a etnografia dos primitivos habitantes do Brasil. Eles não constituíam, aliás, foco de interesse das comemorações, cuja perspectiva foi claramente lusocêntrica.

Os preconceitos da época não permitiam apresentar com igual naturalidade a nudez dos índios nas ilustrações. Em certas obras são desenhados de lado, de forma a esconder os sexos, e noutras aparecem pudicamente cobertos com uma tanga de folhas. Mas as ilustrações do pintor Roque Gameiro captaram em traço vivo os momentos mais significativos do primeiro encontro entre os índios e os marinheiros portugueses, seguindo o relato de Pêro Vaz de Caminha.

Por último, é importante referir a forma como as relações lusobrasileiras foram apresentadas naquele momento especial de celebração. Duas imagens sobressaíam na maior parte dos discursos comemorativos: a paternal e a fraterna. De modo geral, considerava-se que o Brasil era como um filho querido de Portugal, que, tendo alcançado a idade madura, se tinha emancipado do progenitor. Esta ideia salientava a estreita relação histórica existente entre as duas nações e o papel de Portugal como país colonizador. Mas os termos da relação não eram de igualdade, visto que a figura paterna comporta um princípio de autoridade e de superioridade em relação ao filho. Por isso, dada a susceptibilidade dos brasileiros a tudo o que pudesse ser visto como uma forma disfarçada de colonialismo, foi adoptada a imagem de uma relação entre países e povos irmãos. Colocavam-se, assim, os portugueses e os brasileiros no mesmo plano, unidos por uma história comum e por relações horizontais de fraternidade. A imagem e a linguagem tornaram-se recorrentes nas comemorações e até no discurso político-diplomático.

Em suma, a comemoração do quarto centenário do descobrimento do Brasil, apesar de modesta, servia para reafirmar a profunda ligação histórica existente entre os dois países. Pela mão de Portugal se 
considerava que o Brasil tinha, afinal, entrado na História e na Civilização. Esta ideia valorizava a matriz portuguesa na formação do Brasil e circunscrevia os africanos e os índios a uma condição de inferioridade e de invisibilidade da qual só muito lentamente tem vindo a ser resgatados pela historiografia.

\section{O centenário da independência do Brasil}

A 7 de Setembro de 1922, o Brasil ia comemorar com grande aparato o centenário da sua independência, endereçando, portanto, um convite ao presidente da República portuguesa, António José de Almeida, para participar nas celebrações oficiais do Estado brasileiro. A situação política e financeira de Portugal, ainda sob os efeitos do rescaldo da Grande Guerra, era, à época, muito difícil, e havia um acentuado interesse por parte do governo português em melhorar e aprofundar as relações luso-brasileiras, que não eram boas. Basta lembrar que no outro lado do Atlântico vivia uma importante comunidade portuguesa que era o alvo privilegiado das campanhas nativistas e de um ódio difuso alimentado por um certo tipo de populismo. Além disso, tinha-se difundido a ideia de que Portugal era um país atrasado e de que as correntes modernistas demarcavam-se da influência que a cultura e, em especial, os escritores portugueses haviam tido no século XIX. A lusofobia brasileira já tinha dado motivo a fortes reacções na imprensa portuguesa e as relações entre os dois países atravessavam um período de tensão.

Deste modo, a deslocação do presidente da República portuguesa ao Brasil para participar no centenário revestia-se de uma grande importância política e diplomática e podia ser uma oportunidade para aproximar ambos os países. Depois de obtida a autorização parlamentar, constituiuse uma comitiva oficial com algumas figuras nacionais de prestígio e repórteres dos principais jornais. O ministro dos Negócios Estrangeiros levava a missão de concluir a assinatura de vários tratados.

A viagem da comitiva portuguesa foi acidentada e demorou cerca do dobro do tempo normal, devido a problemas vários com o navio utilizado para o transporte. Só a 17 de setembro deram entrada na Baía da Guanabara e foram recebidos de forma muito amistosa pelas autoridades brasileiras. Em termos práticos, o esforço diplomático feito pelas chancelarias de ambos os países saldou-se na assinatura de três 
tratados. O primeiro, sobre a reciprocidade em matéria de propriedade literária e artística, o segundo, sobre a isenção do serviço militar nos casos de dupla nacionalidade, e o último, sobre a protecção do trabalho dos emigrantes. Qualquer deles abrangia assuntos de grande importância para as relações entre ambos os países, mas não se conseguiu o almejado tratado comercial que facilitaria a colocação de produtos nacionais no mercado brasileiro e vice-versa.

O país participou na Exposição Internacional do Rio de Janeiro, a mais importante iniciativa do programa das comemorações brasileiras, com dois pavilhões: o Pavilhão de Honra e o Pavilhão das Indústrias. No primeiro, expunha-se uma mostra bastante significativa das artes e do artesanato nacionais, através de pinturas, esculturas, peças de ourivesaria, rendas, tapetes de Arraiolos e azulejaria. No segundo, evocava-se a história nacional em painéis de azulejos e apresentavam-se as principais produções de Portugal e das suas colónias. A iniciativa do pintor Leal da Câmara de levar um cofre, em forma de coração, com terra de Guimarães e de Sagres, e colocá-lo numa espécie de altar da pátria num dos pavilhões teve um enorme sucesso junto da comunidade portuguesa residente no Brasil.

Mas o acontecimento que teve, de longe, maior impacto no ano do centenário da independência do Brasil foi a primeira travessia aérea do Atlântico Sul, realizada por Gago Coutinho e Sacadura Cabral. A ideia da expedição surgiu na sequêencia da travessia do Atlântico Norte por aviadores norte-americanos e consolidou-se na altura da passagem por Lisboa do presidente brasileiro, Epitácio Pessoa. Em 1919, Sacadura Cabral apresentou o projecto ao ministro da Marinha. Pensava-se que a viagem devia ser levada a cabo por dois aviões, um de cada nacionalidade, e apoiada pela Marinha de Guerra de ambos os países. Uma parceria que não era inédita nos anais da aviação, visto que os norte-americanos e os ingleses assim tinham conseguido ligar a Terra Nova à Irlanda. Mas o governo brasileiro não deu seguimento à proposta, e dois anos depois Sacadura Cabral renovou as suas diligências junto das autoridades portuguesas para associar o projecto às comemorações do centenário.

A ideia da travessia do Atlântico Sul andava a ser discutida em vários países europeus, e Sacadura Cabral defendia que Portugal não podia deixar-se ultrapassar nesta matéria, numa altura em que as atenções da opinião pública estavam voltadas para as proezas dos ares. 
Os seus argumentos colheram adeptos, e o governo português dispôs-se a financiar a empresa. Foram necessários vários meses de estudos e de trabalho intenso para preparar a viagem, cuja principal dificuldade técnica consistia em conseguir orientar a aeronave na longa travessia do oceano durante a noite. Não era também de menor importância a questão do combustível necessário para o largo percurso, que teria de ser feito sem reabastecimento do aparelho.

A ligação aérea Lisboa-Rio de Janeiro tinha-se tornado uma questão de brio nacional. A 30 de março de 1922, o frágil hidroavião levantava vôo do estuário do Tejo para uma viagem acidentada que se prolongaria por mais de dois meses. O percurso foi feito em várias etapas: Las Palmas, São Vicente, São Tiago, o penedo de São Pedro, a ilha de Fernando Noronha e o Recife, já na costa brasileira. Perderam-se na viagem dois hidroaviões, e somente se conseguiu atingir a costa do Brasil no terceiro aparelho. Felizmente, para as horas difíceis e de desânimo, os aviadores tinham levado consigo a epopéia do grande poeta nacional Luís de Camões - Os Lusíadas. Não podiam ignorar a enorme expectativa que havia nos dois países em relação ao sucesso da empresa. Encontrado o objectivo da equipe, frisou Sacadura Cabral: "Chegámos para provar que a nossa raça ainda tem as energias de outrora e para demonstrar que se podia fazer o milagre" (Boletim da Sociedade de Geographia de Lisboa, 1922, p. 423).

A proeza dos aviadores portugueses desencadeou uma onda de entusiasmo e de simpatia extraordinários em ambos os países. Choveram as homenagens e as manifestações de alegria, depois da ansiedade que se tinha vivido na última etapa da viagem, em que se chegou a temer pela sorte dos nautas modernos. No Rio de Janeiro, uma música popular logo registava o feito nos seguintes termos:

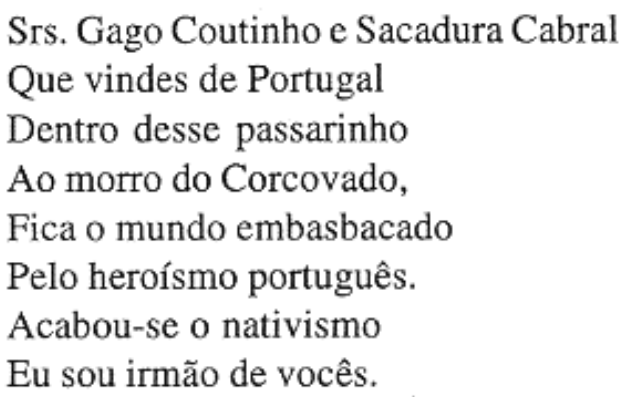


Voltando ao dia 7 de Setembro, data oficialmente consagrada à independência do Brasil, lembramos que ele fora assinalado em Lisboa por espectáculos especiais nos teatros, e a Câmara dos Deputados dedicou parte da sessão da manhã para evocar o acontecimento. Os discursos dos deputados dos vários grupos político-partidários representados no Parlamento traduziram bem a forma como o centenário foi encarado em Portugal.

O deputado da minoria monárquica recordava que a independência do Brasil tinha sido praticamente pacífica: "foi quási uma separação amigável" (Diário da Câmara dos Deputados, 1922, p. 19). A emancipação da colónia era vista como o resultado de um processo natural de desenvolvimento. Tal como um fruto se desprende da árvore quando fica maduro, assim as colónias se libertam da tutela da metrópole quando atingem um certo grau de progresso e autonomia económica, política e cultural. A maturação do Brasil fora precipitada pela ida do rei D. João VI e da corte portuguesa para o Rio de Janeiro, quando das invasões francesas. A abertura dos seus portos ao comércio estrangeiro, o livre exercício de todas as indústrias, a organização da instrução pública e da administração brasileira criaram as condições para a independência da colónia. E dessas várias intervenções depreende-se que tal maturação não era vista como um acontecimento traumático, mas como um motivo de orgulho para os portugueses. A grande nação da América do Sul era, afinal, o fruto da colonização portuguesa e "a maior glória do povo português"; uma glória que alguns consideravam mesmo superior aos descobrimentos ousados nos séculos XV e XVI (Díario da Câmara dos Deputados, 1922, p. 20).

O deputado da minoria católica salientava a ideia de que o Brasil era o resultado da obra de dilatação da cristandade pelo mundo, uma obra que tinha sido levada a cabo pelos portugueses. Por sua vez, outro deputado, republicano e laico, preferia enaltecer o "nobre sentido civilizador" que fez com que Portugal tivesse realizado a epopeia das descobertas e rasgado novos horizontes ao mundo (Diário da Câmara dos Deputados, 1922, p. 22). Na sua opinião, "os ideais duma nação não podem de nenhum modo sobrepor-se aos ideais de civilização e humanidade". Segundo ele, no seu tempo seria difícil "impor a restrição dos princípios de humanidade pelos princípios de nacionalidade". Tinha, decerto, em mente os efeitos terríveis da Grande Guerra e a ideia 
republicana de uma fraternidade universal que, na verdade, não correspondia à prática política corrente no mundo.

No Brasil, o presidente António José de Almeida referia-se ao Brasil e a Portugal como "duas pátrias irmãs" (AlmeIDA, 1933-1934, p. 212). Um passado histórico comum, as mesmas instituições republicanas e a mesma língua eram a base do sentimento fraterno que enleava os corações de portugueses e brasileiros, na retórica de António José de Almeida. Assim, o 7 de Setembro não era visto como uma data exclusivamente brasileira, mas como uma data luso-brasileira e justamente comemorada em ambos os países.

A eloqüência do presidente da República portuguesa e a sua reconhecida habilidade como orador granjearam a simpatia dos brasileiros. O ponto alto da visita diplomática foi atingido na sessão realizada no Congresso Federal quando António José de Almeida agradeceu aos brasileiros, em nome de Portugal, o favor que prestaram aos portugueses "proclamando-se independentes no momento em que o fizeram" (AlMEDA, 1933-1934, p. 238). Em 1822, lembrou ele, Portugal enfrentava tremendas dificuldades. E a independência do Brasil permitiralhe, no fim de contas, preservar o essencial da herança da colonização portuguesa e transformar-se num país de acolhimento dos emigrantes nacionais. Em nenhum momento se esquecia de mencionar que o grito de "Independência ou Morte!" tinha sido lançado por um príncipe português - D. Pedro I do Brasil e IV de Portugal - e que a autonomia do Brasil era também obra de portugueses ali radicados. António José de Almeida lembrou ainda que o mesmo anseio de liberdade, de direito e de justiça que esteve na origem da independência brasileira, teria marcado a história de Portugal naquela época com a revolução liberal. Deste modo, o presidente recuperava a memória do liberalismo e da revolução de 1820 , que era cara ao ideário republicano.

O amplo significado das relações de Portugal com o Brasil, evocado por António José de Almeida durante aquela comemoração, já era valorizado pelos governantes da I República. A questão da história comum, do descobrimento e da colonização portuguesa eram pontos de honra de uma memória nacional que via também na independência um facto natural e inevitável, uma vitória da liberdade e do povo brasileiro comparável à implantação do regime liberal e da própria República, em Portugal. Mas aquilo que, realmente, mobilizava os Portugueses era a 
imagem do papel que tinham tido os seus antepassados na edificação do Brasil. Por isso, a comunidade portuguesa residente no Brasil financiou uma obra monumental, a História da Colonização Portuguesa do Brasil, dirigida pelo monárquico Carlos Malheiro Dias, que ali se exilara depois da implantação da República, em 1910. Tratando-se de uma obra colectiva, em que colaboraram portugueses e brasileiros, as contribuições são naturalmente de qualidade desigual. Se alguns textos continuam a ser uma referência importante, outros perderam a validade e só têm hoje interesse no quadro de um estudo das mentalidades e da evolução das concepções e dos conhecimentos históricos.

O Brasil tinha um lugar especial na memória e no imaginário dos portugueses. A República portuguesa comemorava o descobrimento do Brasil a 3 de Maio, num feriado anual que foi decretado em 1910 e se manteve até à reforma de 1952. Em 1922, o Dia do Brasil foi celebrado a 15 de Novembro, na data da implantação da República naquele país. Posteriormente, nas grandes comemorações nacionais promovidas pelo Estado Novo, o Brasil não deixou de estar oficialmente representado. Em 1940, foi o único país a ter um pavilhão na Exposição do Mundo Português. E, em 1960, o presidente Kubitschek de Oliveira visitou Portugal e participou nas comemorações do Quinto Centenário da Morte do Infante D. Henrique. Aquele ano foi marcado pela crescente contestação internacional à política colonial dos governos presididos por Salazar, e, por isso, o regime fez um grande esforço na frente diplomática para manter as alianças políticas tradicionais. Contudo, em nenhum dos dois casos citados, o Brasil era o objecto das celebrações. Somente sob a égide do regime democrático, após o 25 de Abril de 1974, voltaria a estar no centro de comemorações promovidas pelo Estado português.

\section{O quinto centenário do achamento}

Os aniversários e centenários só podem ser úteis se constituírem ensejo para estudar problemas, meditar directrizes, criticar certezas dogmáticas; caso contrário, mumificam os vivos, sem ressuscitar os mortos. (GodinHo, 1947, p. 14)

Não foi nosso objectivo a exaltação nacionalista. Bem pelo contrário, o que importa é que os povos se conheçam e se respeitem. Que se estimem sem que se pretenda uma visão uniforme, 
que disfarcem os defeitos e vícios. Que não se mostrem relações na aparência idílicas, mas na realidade conflituais. Cada um com as suas qualidades, podemos e devemos juntar-nos para melhor nos entendermos. É um esforço de cidadania o que se exige. (MAGalHÃES; SAlVADo, 2002, p. 21)

As comemorações de 1900 e 1922 decorreram num quadro político dominado pelo facto de Portugal ser um país que possuía um vasto Império. Do ponto de vista ideológico, a ideia da superioridade dos europeus em relação aos outros povos, bem como a ideia da "bondade" da colonização e do domínio que exerciam sobre o mundo, era geralmente aceite pela opinião pública. No plano das intenções e dos discursos oficiais, a finalidade do colonialismo consistia em "civilizar" e "desenvolver" os países colonizados. Nos países do Novo Mundo, as elites que controlavam o poder eram, e são ainda hoje, de origem europeia ou mestiças; e esses países, apesar de terem lutado para obter a sua independência, reviam-se em valores e concepções idênticos aos que eram dominantes na Europa.

No final do século XX, o quadro político e ideológico é completamente diferente. Portugal encerra o último capítulo do Império com a entrega de Macau à administração chinesa e vive uma era pós-colonial. $\mathrm{O}$ país recentra-se sobre si próprio e, com a adesão à Comunidade Europeia, procura na cena internacional um espaço compatível com sua posição de nação europeia e atlântica. Uma parte das elites políticas que detêm o poder em Portugal formou-se nos combates contra a ditadura salazarista, pela democracia e pela autodeterminação das colónias, a partir dos anos $50 \mathrm{e} 60$. Por isso, o ciclo comemorativo dos descobrimentos portugueses que teve início em 1987 e culminou em $2000 \mathrm{com}$ as comemorações do Brasil desenvolveu-se num contexto ideológico e cultural muito diferente dos anteriores: não havia qualquer ideia de domínio ou de superioridade associada aos projectos comemorativos.

As comemorações dos descobrimentos em Portugal inseriramse, portanto, numa política de afirmação da identidade nacional e, por isso, recuperaram do passado os acontecimentos e as figuras históricas considerados mais emblemáticos. Os primeiros séculos da Idade Moderna têm sido para os portugueses, desde a historiografia romântica do século XIX, a sua "idade de ouro" e a forja dos grandes heróis nacionais. 
De tal modo é assim que um observador atento da realidade portuguesa, o ensaísta Eduardo Lourenço, escreveu que a memória dos descobrimentos e da dispersão dos portugueses pelo mundo tem sido um elemento crucial da identidade e da autoconsciência nacional, uma "espécie de bilhete de identidade que cada um traz no bolso interior da sua alma: descobrimos e baptizámos a Terra, de Cabo Verde à Índia, do Estreito de Magalhães às Filipinas" (Lourenço, 1988, p. 11).

Compreende-se, assim, que o fim do Império e as profundas transformações da sociedade portuguesa nas últimas décadas do século XX tenham conduzido a uma necessidade, sentida pelas elites dirigentes do país, de retomar o fio da memória e da identidade portuguesa para projectar o futuro do país. Um futuro em que se julga que Portugal poderá capitalizar a sua experiência como nação que estabeleceu a ligação entre o Ocidente e o Oriente por via marítima e entre o Velho e o Novo Mundo. Sendo Portugal um país periférico no contexto europeu, e até mesmo excêntrico em relação a uma União Europeia cada vez mais voltada para o Norte e o Leste, o papel que os portugueses desempenharam na "abertura do mundo", nos séculos XV e XVI, e as heranças culturais que permitiram criar o grande espaço da lusofonia têm sido vistos como vectores de identificação e de reconhecimento num mundo cada vez mais globalizado. O longo ciclo comemorativo, que se prolongou por mais de duas décadas, inseriu-se em políticas da memória e da identidade assumidas por sucessivos governos do Partido SocialDemocrata e do Partido Socialista. De certo modo, recuperou-se num contexto ideológico muito distinto, uma tradição inaugurada com as grandes comemorações dos centenários do final do século XIX.

Assim sendo, a comemoração da chegada da armada comandada por Pedro Álvares Cabral à América do Sul, em 1500, foi apresentada como uma forma de "mútuo redescobrimento" entre portugueses e brasileiros. O primeiro objectivo estratégico definido pela Comissão Nacional para as Comemorações dos Descobrimentos Portugueses consistia em "estreitar as relações entre os dois povos e Estados", ${ }^{6} \mathrm{e}$ a maior parte das grandes iniciativas apontou nessa direcção. O segundo destinava-se a "promover no Brasil a imagem de Portugal", e, por isso, muitas acções foram programadas para se desenrolar no Brasil, nomeadamente exposições, congressos, espectáculos de divulgação da cultura portuguesa. Em terceiro lugar, apontava-se como objectivo 
apresentar adequadamente a cultura histórica dos portugueses, e, por último, "homenagear aqueles a quem se deve, desde o século XVI até ao século XX, a gesta brasileira dos portugueses".

Os objectivos das comemorações tiveram, por conseguinte, os olhos postos no presente e, apesar de terem como pretexto a viagem de Pedro Álvares Cabral, não privilegiaram somente um acontecimento ou uma figura, espraiando-se por um vasto e diversificado rol de iniciativas culturais. Numa entrevista dada no próprio ano do centenário, o comissário-geral português, o historiador da Universidade de Coimbra, Joaquim Romero Magalhães, afirmava: "não nos cingimos a um recordar necrófilo do passado". ' De facto, passando em revista o relatório de actividades da CNCDP, de 1999 a 2001, apesar de encontrarmos exposições retrospectivas, como "A Construção do Brasil (1500-1825)", que teve lugar no Palácio da Ajuda, deparamo-nos também com outras mais voltadas para o presente, como "Os Brasileiros de Torna-Viagem", sobre a emigração e o retorno dos portugueses, ou os "Olhares Modernistas", em que os pintores brasileiros contemporâneos estiveram em foco. O conhecimento e a divulgação da história andaram a par das iniciativas destinadas a promover a criação cultural, como numa exposição de pintura actual que apresentou as "Leituras da Carta de Pêro Vaz de Caminha", de que foi comissário José Augusto-França. Além das exposições, a diversidade dos programas mostra que houve uma preocupação lata de promover e divulgar a cultura portuguesa e a brasileira: muitas edições de obras, intercâmbio ao nível académico e de investigação, espectáculos e animação cultural, com destaque para séries documentais nas televisões. Do ponto de vista da memória colectiva, a única ideia forte foi a do papel essencial dos portugueses na "invenção" ou "construção" do Brasil. Mas nas múltiplas actividades desenvolvidas pela CNCDP, não se esqueceram os elementos indígenas e africanos, e não se perdeu de vista que o Brasil é fruto de múltiplos sincretismos.

No seu discurso em Porto Seguro, o Presidente da República Portuguesa, Jorge Sampaio, afirmou nessa ordem de ideias:

Estamos na origem desta nação e disso nos orgulhamos, mas nunca pretendemos que o nosso contributo tenha sido único, nunca nos arrogámos exclusivos fundadores ou progenitores de um Brasil que é grande na exacta medida da multiplicidade e da 
diferença dos povos que contribuíram para a sua identidade. (Jornal de Notícias, 2000)

"Nunca" é uma força de expressão retórica, obviamente. A grande diferença em relação aos centenários anteriores consiste em ver o Brasil como uma realidade cultural distinta, que não se compadece com a invocação de parentescos. Jorge Sampaio vai ainda mais longe quando vê a grandeza do Brasil como resultado da sua diversidade.

No âmbito da Educação, uma das iniciativas realizadas consistiu em reunir professores portugueses e brasileiros para debater os respectivos programas de ensino da História e as visões que, em cada um dos países, se apresentam do outro e da história comum aos jovens. Este género de iniciativas teve antecedentes em comissões mistas francoalemãs e luso-espanholas, onde se discutiram as visões da História comum nos programas de ensino. O diálogo e a troca de ideias entre profissionais do ensino e da investigação da História não é difícil, porque não se trata de escamotear o passado nem de apresentá-lo em tom róseo. Trata-se de dar importância à reconstrução de uma memória histórica comum, devidamente informada e crítica. As sociedades e os seres humanos de outras épocas viviam e comportavam-se segundo códigos diferentes daqueles que a disciplina de História permite conhecer e, em certa medida, explicar. As sociedades actuais não são responsáveis pelo que aconteceu, mas pelo que acontece. A História pode ajudar a tomar consciência dessa responsabilidade e a ponderar as múltiplas opções que se colocam aos cidadãos de hoje para o futuro.

Além da Comissão Nacional, funcionou em Portugal um Grupo de Trabalho do Ministério da Educação para organizar as comemorações dos descobrimentos portugueses, com o objectivo de dinamizar as comemorações nas escolas dos ensinos básico e secundário. Do seu programa muito variado de actividades destacaram-se, em 2000, publicações destinadas a dar a conhecer a história da colonização e da independência do Brasil, exposições, intercâmbios de estudantes e de professores, concursos e o apoio aos projectos desenvolvidos em escolas de todo o país. Um congresso luso-brasileiro tinha decorrido no final do ano de 1999, sobre o tema genérico "Portugal-Brasil: Memórias e Imaginários". O congresso reuniu a participação de 153 professores e investigadores de ambos os países (Actas do Congresso Luso-Brasileiro "Portugal-Brasil: memórias e imaginários", 2000, p. 744 e 865). 
Tendo sido uma das pessoas responsáveis pela elaboração e coordenação do programa de acção deste Grupo de Trabalho, posso testemunhar que houve uma preocupação de fornecer aos professores e aos estudantes portugueses instrumentos de trabalho para conhecer melhor pelo menos a história do seu país. Em Portugal, os programas incidem sobre a história da Europa e só de forma subsidiária se referem aos outros continentes e povos do mundo. A própria história nacional aparece intercalada na história geral europeia. A perspectiva de aprendizagem da história é, por conseguinte, eurocêntrica para o nível etário dos 12 aos 17 anos. Por isso, apostou-se na produção de materiais para o ensino/aprendizagem da história de Portugal - publicações de fontes, de estudos, videogramas, exposições de cartazes, cadernos didácticos. ${ }^{8}$ Várias obras foram também editadas, com o patrocínio do Grupo de Trabalho, para dar a conhecer melhor a história do Brasil: A construção do Brasil, de Jorge Couto, A História da colonização portuguesa do Brasil, de Maria Beatriz Nizza da Silva, e A Independência do Brasil, de Maria Cândida Proença.

Ao contrário das comemorações do descobrimento do caminho marítimo para a Índia, que suscitaram, em 1998, alguma polémica na imprensa portuguesa (HespanHA, 1999), ${ }^{9}$ o quinto centenário do achamento do Brasil foi pacífico em Portugal. As iniciativas promovidas pela CNCDP e por outras entidades públicas e privadas foram, de modo geral, bem acolhidas pela sociedade portuguesa. Mas não houve acções que implicassem grande mobilização pública nem verdadeiro entusiasmo. $\mathrm{O}$ programa comemorativo diluiu-se em múltiplas actividades que foram decorrendo ao longo do ano, sem sobressaltos e com um impacto geralmente limitado. Pontualmente, ouviam-se os ecos, na comunicação social, de declarações ou de reacções do lado brasileiro que mostravam a agitação contra as comemorações oficiais. Chegavam reportagens de reivindicações dos povos indígenas e de uma memória colectiva que ainda continua a responsabilizar a colonização portuguesa pelos problemas económicos e sociais do Brasil, quase dois séculos após a independência. Confrontado com essa ideia, um professor português de História e autor de manuais escolares, Arlindo Caldeira, replicou com "bom humor" em entrevista à Folha de S. Paulo: "Vocês já tiveram tempo bastante para corrigir isso..." Aliás, deste lado do Atlântico, a "má sorte brasileira é mesmo ser Índio", ${ }^{11}$ como expunha o título de um jornal diário a propósito 
da carga policial na Coroa Vermelha, e parece bizarro continuar a culpar o passado colonial e os portugueses pelas desgraças do Brasil.

Muito difícil é saber qual o efeito das comemorações na consciência histórica e na memória colectiva dos portugueses. Muitos vão continuar não identificando o nome de Pedro Álvares Cabral, como é evidente. A maioria da população tem uma ideia muito vaga da história nacional, apesar de ser escolarizada, e as comemorações não conseguem mudar essa realidade. Contudo, os ciclos comemorativos dos descobrimentos parecem ter contribuído para fixar a ideia de que os séculos XV e XVI foram a "idade de ouro" da nação. O que a memória colectiva mais facilmente retém são os aspectos positivos que aparecem ligados a temas como o papel pioneiro dos portugueses nas grandes navegações oceânicas, o contributo para a "abertura do mundo" e para o desenvolvimento dos conhecimentos científicos e técnicos. Mas é impossível hoje, excepto em casos de assumida cegueira ideológica, manter uma visão linear e exclusivamente luminosa da História.

O tema do "encontro dos povos" foi introduzido nas comemorações espanholas das viagens de Cristóvão Colombo e suscitou imediatamente controvérsia, porque escamoteia o desencontro, o conflito. Os historiadores preferem o termo "contacto" por ser neutro e não dar azo a uma falsa ideia de igualdade, de horizontalidade das relações que está subjacente ao termo encontro. De facto, as relações entre os povos foram, e são ainda hoje, desiguais e enquadradas por formas de domínio e de poder que é preciso ter em conta para perceber a realidade. Mas a expressão "encontro dos povos" teve um eco forte na sociedade portuguesa, porque entronca numa ideia muito generalizada sobre o carácter aberto, amigável, avesso à discriminação que, supostamente, teria caracterizado a forma portuguesa de estar no mundo e os contactos com os outros povos. Esta noção foi defendida, no Brasil, por Gilberto Freyre e teve uma repercussão considerável em Portugal, se bem que tenha raízes anteriores ao Estado Novo e já se encontre de forma difusa em autores portugueses do final do século XIX e da I República. É uma visão que olha o passado pelo lado que melhor serve uma auto-imagem positiva, simpática, mas que tem também contribuído para promover valores humanistas e anti-racistas entre os portugueses. Além disso, num contexto pós-colonial, o tema do "encontro dos povos" parecia ser 
o ideal para construir um imaginário de aproximação, de diálogo e de intercâmbio, tendo em vista já não o passado, mas o futuro.

A contestação e a crítica pertinente à expressão "encontro dos povos" demonstram bem a dificuldade de estabelecer os consensos necessários às comemorações nas sociedades democráticas e plurais da actualidade. A circulação das ideias e da informação coloca em evidência a fragmentação das memórias, que é, afinal, resultado das profundas clivagens do mundo. Os grandes quadros ideológicos que tinham permitido estabelecer uma certa unanimidade em torno de determinados valores e visões do passado estão em completo declínio. Por isso, as celebrações públicas tornam-se palco de confrontos latentes nas sociedades ou passam discretamente entre inaugurações de exposições, eventos académicos e espectáculos em que o propósito comemorativo se perde de vista. As festas decretadas pelas autoridades são "uma espécie de missa de secretaria", como muito bem observou Oliveira Martins (1877). Excepto em circunstâncias excepcionais, capazes de despertar fortes emoções colectivas, as comemorações costumam ser rituais frios e efémeros. O que fica para a posteridade é, afinal, o fruto do estudo, da reflexão e da produção cultural feitos com propósitos menos imediatos.

\section{Abstract}

This paper seeks to explore the relationship between memory and commemoration in lusobrazilian history. It analyses the diverse commemorations on Brazil's discovery (1500) by the traveller Pedro Álvares Cabral in both countries since the XIXth century till 2000. It shows the different constructed images on the lusobrazilian imagined community.

Key words: collective memory, commemoration, Brazil's discovery.

\section{Notas}

1. Escreveu Lévi-Strauss: "A humanidade acaba nas fronteiras da tribo, do grupo lingüístico, por vezes, mesmo da aldeia; a tal ponto que um grande número se designam por um nome que significa os "homens" (ou por vezes - digamos com mais descrição - os "bons", os "excelentes", os "perfeitos"), 
implicando assim que outras tribos, grupos ou aldeias não participam das virtudes - ou da mesma natureza - humanas e são, quando muito, compostos por "maus", "perversos", "macacos da terra" ou "ovos de piolho". Chegando-se mesmo, a maior parte das vezes, a privar o estrangeiro deste último grau de realidade fazendo dele um "fantasma" ou "aparição". Assim acontecem coisas curiosas onde os interlocutores se dão cruelmente réplica. Nas Grandes Antilhas, alguns anos após a descoberta da América, enquanto os espanhóis enviavam comissões de investigação para indagar se os indígenas possuíam, ou não, alma, estes últimos dedicavam-se a afogar os brancos feitos prisioneiros para verificarem através de uma vigilância prolongada se o cadáver deles estava, ou não, sujeito a putrefacção" (1980, p. 21).

2. Parece ter sido o caso do 7 de Setembro recentemente comemorado com o patrocínio do governo do presidente Lula da Silva, que pretendeu tornar mais "populares" as celebrações e dar-lhes um maior élan junto do público (Estado de S. Paulo e Folha Online, desfile do 7 de Setembro em imagens em www.guiamarau.com.br/eventos/7set2003).

3. Portugal, Madeira e Açores, Lisboa, 5 e 13 de maio de 1900.

4. Sobre o monumento, ver a revista O Occidente, v. 23, n. 768, 30 abr. 1900.

5. Brasil-Portugal, $2^{9}$ ano, Número Extraordinário, fevereiro de 1900 a fevereiro de 1901, Lisboa, 1901.

6. Citações do programa estratégico apresentado no sítio da CNCDP www.cncdp.pt -, que, entretanto, já foi desactivado, devido à extinção dessa comissão em 2002.

7. Entrevista a Romero Magalhães, feita por Cláudia Rodrigues, Redacção do Terra Natal - www.terranatal.com/notic/entrev/e_cncdp_8.htm.

8. Ver relatório de actividades: "A Escola e os Descobrimentos: Síntese e Balanço das Comemorações (1988-2000)". Lisboa, 2001.

9. Ver relatório da CNCDP, coordenado por Hespanha (1999).

10. Dos entrevistados pelo Datafolha, na cidade do Rio de Janeiro, 53\% concordam - totalmente ou em parte - com a ideia de que os problemas económicos do Brasil são resultado do modelo de colonização adoptado pelos portugueses. "TV cria o perfil do brasileiro, não a escola, do enviado especial a Lisboa" in FolhaOnline - www.uol.com.br/fol/brasil500/ 500_17htm.

11. Título de um artigo no Jornal de Notícias, 24/4/2000. 


\section{Referências}

Actas do Congresso Luso-Brasileiro "Portugal-Brasil: memórias e imaginários". Lisboa, 2000. v. 1/2.

AlmeidA, António José de. Quarenta anos de vida literária e política. Lisboa, 1933-1934. v. 4.

ANDERSON, Benedict. Imagined Communities: reflections on the origin and spread of nationalism. London-New York: Verso, 1991.

Boletrm da Sociedade de Geographia de Lisboa. Lisboa: Imprensa Nacional, série 40, n. 10/12, out./dez. 1922.

Boletim da Sociedade de Geographia de Lisboa. Lisboa: Imprensa Nacional, serie 19, n. 1/2, jan./fev. 1901 .

Brasil-Portugal. Lisboa, ano 2, Número Extraordinario, fev. 1900/fev. 1901.

Couto, Jorge. A construção do Brasil. Lisboa: Cosmos, 1995.

Dí́rio da Câmara dos Deputados, sessão n. 152, 7 set. 1922.

FonseCA, Faustino da. A descoberta do Brazill. Lisboa, 1900.

GodınHo, Vitorino Magalhães. Comemorações e história. Lisboa: Cadernos "Seara Nova", 1947.

. O papel de Portugal nos séculos XV e XVI: que significa descobrir? Os novos mundos e um mundo novo. Lisboa: Grupo de Trabalho do Ministério da Educação para as Comemorações dos Descobrimentos Portugueses, 1994.

Heródote. Histoires. In: Fremeaux, Jacques; Valette, Bernard. L'écriture de l'histoire. Paris: Marketing, 1980.

Hespanha, António Manuel (Coord.). Há 500 anos: balanço de três anos de comemorações dos descobrimentos portugueses (1996-1998). Lisboa, 1999.

JoRnal de Notícias, Porto, 23 abr. 2000. Disponível em: <htttp://jn.sapo.pt/ arquivo/noticia.

LÉvi-Strauss, Claude. Raça e historia. Lisboa: Presença, 1980.

Lima Cruz, Maria Augusta; JoÃo, Maria Isabel. A escola e descobrimentos: síntese e balanço das comemorações (1988-2000). Lisboa, 2001.

Lopes de Mendonça, Henrique. Terra de Santa Cruz. Lisboa, [s.e.], 1899.

Lourenço, Eduardo. Nós e a Europa ou as duas razões. Lisboa: Imprensa Nacional; Casa da Moeda, 1988.

Magalhães, Joaquim Romero; Salvado, João Paulo (Coord.). Relatório de Actividades da CNCDP 1999-2001. Lisboa, 2002. 
Oliveira Martins, P. Paulo Rubens. Os dois mundos. Illustração para Portugal e Brazil, 1 v., n. 2, Paris, 30 set. 1877.

PIMENTEL, Alberto. O descobrimento do Brazil. 2.ed. Lisboa, [s.e.], 1900.

RiberRo, Gladys Sabina. A guerra aos portugueses no Rio de Janeiro no final do século XIX. Oceanos, n. 44, p. 69-84, out./dez. 2000.

Rowland, Robert. Antropologia, história e diferença: alguns aspectos. 2.ed. Porto: Afrontamento, 1987.

Wachtel, Nathan. La vision des vaincus: les indiens du Pérou devant la conquête espagnole (1530-1570). Paris: Gallimard, 1971. 